\title{
Nigeria's Fourth Republic-Democratic or Civil Rule: An Assessment of the Situation Since 1999
}

\author{
Enyi John Egbe, Ph.D \\ Senior Lecturer Department Of Political Science, Benue State University, Makurdi, Nigeria
}

\begin{abstract}
This paper assesses practice of democratic governance in the present Republic. Concepts of democracy and civil rule were reviewed. the elite model was adopted for the analysis of the paper. The features of a democracy like freedom of information, popular and direct participation, credible electoral process, discipline, honesty, openness, transparency and accountability, periodic free and fair elections etc. situating the above in the Nigeria's Fourth Republic, The paper finds out that Nigeria has not improved beyond what existed in the military era. The Nigeria's Fourth Republic democracy is rule by the minority through alienation. Leadership in the Nigerian Fourth Republic is not people oriented as their ascension to power is through unethical means. The judiciary does not have true independence and this rubs them of their role as the last hope of a common man. The paper concludes that there is no democracy in Nigeria. Democracy anywhere it is practiced must be seen through its tenets and these are not on ground in Nigeria. Thus, Nigeria has only experience an uninterrupted civil rule in the Fourth Republic. The paper recommends that for an entrenchment of democracy in Nigeria, the citizens must sit up to see that democratic tenets are adhered to. Again, there must be freedom of the electorates which makes the difference between enslavement and liberation. This is only possible if the electorates are allowed to exercise their franchise in choosing who should lead them. All these can be done when there is the observance of the rule of law and the supremacy of the constitution.
\end{abstract}

\section{Introduction}

On $29^{\text {th }}$ May, 1999, there was a change of baton in the leadership and governance in Nigeria from military to civil administration. This followed a drama that went for an election which was conducted by the military after enacting the 1999 Constitution. Many Nigerians heaved a sight of relief. The people were of the belief that, at last, the undemocratic, autocratic, authoritative, illegitimate, repressive and the absence of equity and justice in governance relationship with the people will be replaced by constitutionality, legitimacy, justice, fair play, freedom, in one word, a democratic form of government.

The people also believe that democracy is a system of government which allows for adequate representation of the people at the three tiers of government (i.e. federal, state and local governments) and that in no time the dividends of democratic rule would soon trickle down to all the facets of life. But after thirteen (13) years into the present democratic experience with the transformation from civil to civil rule in 2003, 2007 and 2011 tongues are wagging whether or not the nation is moving ahead in the spirit of democracy or not.

As the populace get more and more repressed and alienated in the much desired or awaited civilian administration, the absence of equity and justice in government relationship with the large segment of the population become a matter of consideration. This is because of government and governance regrettable inability to address the problems that brought them into existence. This paper therefore sets out to ascertain whether Nigeria that is not new in the practice of or the idea of democracy as well as the presidential system of government is really practicing democracy that is much talked about or is still tramping with civilian rule under the guise of nascent democracy in the Fourth Republic.

Before we reach the meat of the topic, we must be thoroughly informed or knowledgeable about the concept of democracy and civil rule. Again, to do justice to this topic, it is necessary and pertinent to examine a theoretical framework that would serve as a guide for analysis. To this end, the elite model is adopted for the paper. The characteristic features of democracy are outlined and discussed. The paper evaluates the Nigeria's Fourth Republic on the tenets with conclusion and recommendations.

\subsection{Conceptualizing Democracy}

Democracy has been defined in various ways by a number of scholars. However, when we talk of democracy, we cannot do without the participation of the people upon whom the fulcrum of democracy rests. It may be said to be the government of the people by the people for the people (Babawale, 2003:204) quoting Lincoln. Schumpeper (1942) views it as a method by which decision making is transferred to individuals who have gained power in a competitive struggle for the votes of the citizens. Dahl (1989:221) advanced a more 
comprehensive definition of democracy which describes the essential ingredients for democracy to function, such as:

a. High level of civil liberties

b. Political Pluralism (extensive competition by contestants including individuals, groups or parties for government) and

c. Political participation that provides the choice of the electorates to select candidates in free and fair elections.

A more elaborate description has been offered by Elaigwu (2004) who sees the term democracy as having five important characteristics. The first relates to the locus of authority in a democratic polity. Political authority originates from the people. Therefore any authority that is not a product of the people's consent is not democratic. The second characteristic of democracy is that as a system of rule it must be based on the rule of law. This means that the application or enforcement of law cannot be arbitrary hence there are specified limits to power and how it can be used. The third characteristic of democracy is that any polity under democratic rule must be legitimate which means that the leader has the right to rule and is ruling rightly. This logically means that the leader must perform well, "giving the ends for which he was elected" (Elaigwu, 2004:5). There is yet the fourth element of democracy namely choice. The people should have a right to effect changes in their leadership through periodic and regular elections. Finally and closely related to all these elements is that of transparency and accountability. A democratic polity must be able to ensure transparency in the conduct of government affairs. Political leaders must also be "held accountable for their actions as representatives of the people who are trusted with power to achieve certain ends" (Elaigwu, 2004:67). In his own view Heater (in Enemao, 1999) posited that democracy may be regarded as a form of government, a way of life, an attitude of the mind, essentially a method of organizing society politically.

It suffices to describe democracy as a system that allows people to decide when, where and how to choose their leaders. Such decisions are not an end in themselves, but they are based on the need for the leadership to perform well, be ready to subject themselves to free and fair elections as and when necessary, and be willing to accept the outcome of such elections in good faith. (Oludoyi, 2006:17). He maintains that, "Under such a system, good performance by the leadership is expected to attract reward. For instance, re-election, respect and obedience of the followership. While poor performance should lead to sanctions either legally or morally".

In this paper, democracy is construed along the lines of its basic features: popular participation in the decision making process, open and fair competition within firmly and generally accepted rules of the game and the normative dimension that consists of the acceptance of majority rule, respect for the rule of law, protection of individual and minority rights and safeguarding the interest of the disadvantaged group in the polity.

\subsection{The Concept of Civil Rule}

There is a dearth of literature on the concept of civil rule. This is because it has been established that, democracy is civil rule. This however, is not true in many African countries and Nigeria in particular. In the western world especially in America, there are agitations for a republic as an ideal form of government rather than democracy. Soueze (2005) avers that civil rule is not necessarily the same with democracy. Thus, in this paper we can define civil rule to mean the transfer of governance from the military to the civilians through a sporadic elections that de-emphasize the electoral processes and freedom of the electorates.

In such a situation, the masses and their natural endowments work for the benefits of the few privilege people. A characteristic of civil rule is that, rather than the supremacy of the constitutions, there is the supremacy of political leaders who decide how long a leader remains in power and when elections will be conducted. The fact that the leadership is supreme, the freedom of choice and expression which are kennels of good governance are restrained.

The above is a classical case of what we have in Nigeria. To Wakaman and Gabas (2009:15) "Politics rule the world, democracy rule the people, Nigeria has neither yet we are in a civil rule and we are even about to roll out drums albeit on a very modest scale to shout ... we got the military back to the barracks". To them, Nigeria has taught the world the difference between democracy and civil rule. Continuing, they said "We have just taught the world that it is possible not to be in a dictatorship but at the same time not to have democracy. Democracy is a system in which the people's natural endowments work for the people and not for a privileged few" (Wakaman and Gabas 2009).

\section{Theoretical Framework}

The elite theory is adopted as a guide for the analysis of this work. Elite approach can either be conservative or radical. It was used in European countries to criticize democracy and socialism. The founding fathers of this theory include: Gaetano Mosca (1939) Robert Michels (1942) and Laswell (1948). All these 
theorists used conservative analysis to explain elite theory. However, Mills C.W. in Olaniyi, (2001:89) says the power elite is a radical analysis.

Furthermore, Mosca Gaetano (1939) in Olaniyi (2001:89) noted that the distinguishing characteristics of the elite are the attitude to command and to exercise political control. The conceptual scheme postulated by elite theorist comprises the following generalizations: In every society there is and must always be a minority which rules over the rest of society. This nation is compatible with Pareto's view that in all human societies be it capitalist or socialist, simple or complex, there is a ruling elite which rules over all other members of society. According to Bill et al. (1973), the political elite is that group which possesses most of political power and which makes most significant political decisions in a society. It is composed of that minority of individuals who are most active in political affairs. Elite theory therefore helps to provide a common basis for comparative analysis of the behavior of political actors in a political system. Also Pareto (in Bill 1973:73) supports this view when he says that, "every people is governed by an elite, by a chosen element in the population...it is always an oligarchy that governs".

The theory assumes that all men love power; that men are not endowed alike. There are diversities stemming from physical environment, birth and history, rather than equality, inequality is everywhere. The elitist structure of society which divides society into two classes merely reflects this ambiguity of inequality.

This theory is criticized on the use of which power is put. There is no way by which the elites can use power to benefit all and sundry in the society. Elite theory is also criticized on the assumption that the elite group is homogenous group conscious of their power. It assumes the sanity, coherence and self consciousness of the elite. According to Dahl (1976) the elite model is anti-democratic. He admitted that there was multiplicity of elites in USA. The contention of the classical theorist is that all governments are oligarchies and that democracy is fraud. This paper found the theory useful in the analysis of this work.

\section{Democracy or Civilian Rule in Nigeria: An Assessment}

The thrust of this paper is to assess governance in the Nigeria's Fourth Republic as to whether a true democracy is in place or a mere civilian rule. To do justice to this section of the paper, the principles or tenets of an ideal democracy will be analyzed and based on these tenets to determine her position, that is, whether there is-democratic rule or civilian rule in Nigeria in the current political dispensation.

Democracy has been refined by placing before it adjective such as popular, direct and participatory tenets. Yet to Adeyemi (2004:41) "The fall of Berhin Wall and the ensuring demise of totalitarian systems in Africa and across the world have demonstrated that no matter how democracy is characterized, labels are meaningless if certain ideals and principles do not exist".

Thus, to talk of democracy there are a lot of things that need to be done. This is because democracy itself requires the establishment of structures, mechanisms and institutions. This is why Igbuzor argued that "Democracy has to permeate every facet of society, the way of doing things in institutions has to be democratic, the electorates should be seen to have elected their representatives," (Leadership, Sunday June 21, 2009).

Thus in a political realm, the greatest responsibility is on political elite which must reflect democratic principles for us to have democracy. This implies that, within the political parties, internal democracy should be prime. Also for there to be a democratic rule there must first of all be a credible electoral process; such a process according to Nyityo (2009:9) must include the following tents: first the mandate to the office(s) being aspired to must be secured in a freely competitive and fair atmosphere. Second, the officers who are vested with the responsibility to conduct elections must be men of integrity, morally upright with a good conscience and not given to corrupt tendencies. Other core values to be considered and imbedded by the operators of a credible electoral process should among other things include discipline, honesty, openness, transparency and accountability.

The electorate on its own part must respond in a positive manner to enhance the good working of the electoral process. Democracy must uphold principles such as fair political representation, free elections, equal rights, individual freedom, accountability, tolerance and peaceful resolution of conflicts. More importantly, Adeyimi (2006:4) avers that "The protection of human rights lies at the heart of democracy for it ensures the right of every citizen to live without fear and to live in peace". Let us quickly add here that there should also be election of ward officials, local government party officials, state government party officials and federal government officials in a genuinely conducted elections supervised by an impartial umpire. There should be no imposition of candidates and insistence that other candidates should not contest as is often the case in Nigeria currently. Very often elections are characterized by ballot box snatching, allocation of votes, and rigging in various forms. The chairperson of the National Electoral Commission of Sierra-Leone also emphases that:

It is crucial that there is public confidence in the electoral process in order for the citizens to believe in the authority and legitimacy of their government. It is worth noting that a credible electoral process cannot be separated from other general considerations such as the political climate, the rule of law, mechanism for the 
enforcement of legal and human rights, media freedom, neutrality of the security forces and the impartial operation of an Independent Electoral Management Body. (Daily Trust April, 2009, p.5).

The centrality of the above can be seen in the fact that, genuine democratic elections are the vehicles through which the people of a country freely express their will on the basis established by law as to who should have the legitimacy to govern in their name and interest.

The question that we need to pose at this juncture is whether governance in the Nigeria's Fourth Republic has improved beyond that which existed in the military era or Nigeria is merely practicing a civilian rule. This leads us to an analysis of the challenges of the Nigerian democracy. According to Igbuzor, in the Leadership of Sunday June 21, 2009. 'We had no democracy for ten years but civilian rule. According to him, there is a difference between democratic governance and civilian rule. He maintains that:

There is the perception of ten years of civilian rule. As at May 29, 1999 there was a high level of expectations and enthusiasm that greeted our returning to civilian rule. But those wishes were clearly dashed by the end of Obasanjo's regime and they have remained unfulfilled in the last two years of this administration.

Another tenet of democracy is a credible electoral process. In Nigeria, the opposite is the case. There was a time in the life of this nation (Nigeria) from independence to the end of the first republic when talk about patrons/clients and the benefits accruing from it constituted an important basis for political mobilization. Such concepts cited above according to Nyityo (2009:11) have disappeared from the political lexicon. Thus "we now talk about godfatherism without godsons. The godfathers have long stopped producing God-fearing offspring. Rather, they produce political thugs with all kinds of menacing campaigns and on election days to snatch ballot boxes from law abiding citizens".

On his part, Igbokwe (2001:1) is of the view that nowhere in the failure of the democracy project more pronounced than in the conduct of elections. The three general elections held under the present democracy were acts that shamed and mocked democracy. He further went on to say that:

What is more, the proceeding elections always turn out better than the ones held thereafter. Thus, while the 1999 arranged elections were deemed better than the 2003 vote allocation, the 2007 farcical charade that drew worldwide opprobrium remains the topping to deliberate electoral frauds that were committed to preserve the most audacious and corrupt wing of what passes as the country's political class in power.

There is at the moment a specter of instability hunting the Nigeria's Fourth Republic. This is evident in the total breakdown of law and order in the Niger Delta, during the early Yar'Adua Administration the Boko Haram menace, the lack of cohesion between the executive and the Legislature and the near cancellation of many elections by the judiciary, the wave of deflections from one party to the other in the National and State Assemblies currently going on has threatened the very foundation of the Nigerian polity.

If democracy is government of the people by the people for the people or put in another way, majority rule, the Nigeria's Fourth Republic democracy is government by alienation and majority rule. Nothing mocks our supposed democratic experience more than the fact that the people have been violently removed from the process. Both in selection and in the application of the democratic tenets, the people have been ostracized and made to feel less important. It is not curious that more than thirteen years into democracy, Nigeria is being made to live with the most macabre, absurd, vicious and fraudulent electoral exercises known to mankind. It is strange that more than thirteen years into democracy, the only business that thrives in Nigeria remains the mindless pillaging of the country's resources by a thieving political class that have invented newer ways of reaping off the entire country, (Igbokwe, 2009).

Trust worthy and people oriented leadership is also central for the enthronement of democracy in a country. In Nigeria, the position of our leaders is succinctly explained by Gana, in the Daily Trust October, 28, 2008 thus "our leaders have no ideas, there is no creativity and when there is not idea, there is no knowledge. Where there is no knowledge, the people perish". An acute leadership atrophy had ensured that those occupying leadership positions in the country remain blighted in their approaches to governance. The narrow and selfish interest of the few that accessed political offices, mostly through fraudulent, violent and culled means has successfully replaced the interest of the people for which they yearned and longed for democracy. The Nigerian political class from councilors to chairmen to legislators at all levels and even the executive class are so obsessed with power and primitive accumulation and all other things have been relegated to the background. Most politicians are now preoccupied with building mansions in their villages, in their local government headquarters, in their state capitals and ultimately at Abuja when salaries sometimes remain unpaid, not to think of development. Their mentality is to acquire as many awards as possible even when they do not merit them.

Scholars like Ake (1996) and Ahuahene-Gima, (2011) have written extensively on the mentality of African leaders, Nigerian leaders inclusive. For instance, Ahuahene-Gima in "The Nation" Newspaper of 
Wednesday, November 30, 2011, gave a scathing description of the way in which some African politicians operate when he said:, "when they get into power our leaders think that their role is to distribute wealth-they do not create anything new. We also have 'fanfare' leaders; they like to win awards, so they first distribute wealth to their inner circle at the detriment of the economy". What is more Nigerian leaders are corrupt, lack vision and commitment to the development of their areas. When they demand autonomy, it is not for development but for their selfish reasons. They want autonomy to accumulate, not autonomy to optimize resources allocation to the grassroots people. A massive orientation of political actors is necessary in this area". Odo (1994).

In this wise, democracy had come to lose its flavor and meaning amongst Nigerians. While the sybaritic interests of those in government have grown to unmanageable proportion, the basic needs of the people have been neglected and treated with total distain, (Igbokwe, 2009).

It is in line with the above that Obasanjo in an interview with Daily Trust, April 30, 2009 had this to say: 'in 1999, Nigeria was looking for a president that will build roads, fix power or provide water. Nigeria was not looking for the a president that will hold Nigerians together. The situation in which we found ourselves that time was difficult. Some people even believed that trying to lead Nigeria at the time was wasted exercise'. It is interesting for one to ask whether the party under whose platform Obasanjo won the election had a party and election manifestoes characteristics of democratic governance. The scenario above is aptly captured in the description of the African democracy by Ake (1996;6) that;

What is being foisted to Africa is a version of liberal democracy reduced to the crude simplicity of multiparty elections. This type of democracy is not in the least emancipator especially in Africans conditions because it offers the people rights they cannot exercise, voting that never amounts to choosing, freedom which is patently spurious and political equality which disguises highly unequal power relations.

Again, Balarabe in the Vanguard of $24^{\text {th }}$, May 2009 asserts that "What we have is a mere civilian rule and not democracy. We have rulers who are not in military uniforms, ye are dictators and tyrants which are traits you see in military regimes" Thus, widespread insecurity, alarming spread of vicious circle of poverty, an increasing state of fear and anxiety which have all added to deal a vicious blow on helpless Nigerians who with mouth agape wonder if this is really a democracy they longed for with all their breath, (Igbokwe, 2009). For this there is a near total collapse in the health sector, education, power among other infrastructural facilities in the country. The masses or the poor are getting poorer while the leaders live in affluence. The above is evidenced in the current spate of strikes in the country-the Medical Practitioners strike, the ASUU, ASUP and COEASU strikes which led to closure of Universities, Polytechnics and Colleges of Education for over six months in 2013 throughout the country.

Transparency and independence of the judiciary are far from reality in Nigeria. Rather than being the last hope for the common man, the Nigerian judiciary is the last hope for our unimpeachable leaders. Also, transparency is deemphasized when the interest of the leaders are at stake. This is why those who constitute the Nigerian leadership in the Fourth Republic are mostly people that accessed their ways to power through the most dubious means and that is why things continue to worsen in the country. It is heart breaking that countries such as South Africa and Ghana continue to gain in International recognition in Africa, Nigeria continues to draw derisive asides. Two clear demonstrations of the derisive low level Nigeria has sunk were the invitation to the recent G.20 Summit in London where Nigeria was not even allowed an observer status, (Igbokwe, 2009). The second one is the fact that a country like Ghana has got its acts right as far as democracy is concerned by holding a successful elections in recent years without any form of violence. Awoyifa, Abah and Onyeche (2009:2) quoting the former Minister for Information, Dr. Walter Ofonagoro explain thus:

Why do you think president Obama will be visiting Ghana in July? It is because Ghana is practicing true democracy. If we want people to take us seriously, we must also practice true democracy. A situation whereby one sit somewhere and determine who become the local government chairman and the one who becomes the governor and those who will go to the senate, that is not democracy.

This is clear indication that democracy does not have two names. Anywhere it is practiced with all its tenets, it can be argued that democracy is on ground. In 2007, European Union were invited and accredited to observe the elections in Nigeria, but when their report did not favour the ruling party, the Senate President David Mark reacted thus: "Your criticisms, comments and suggestions are welcome, but the final decision lies with the Nigerian people. Nobody can claim to love Nigeria more than Nigerians themselves. I know no body would do anything to destabilize Nigeria... no two democracies are the same anywhere in the world" (This Day, August 23, 2007).

It is doubtful whether one can talk of democracy in the absence of popular participation, fair competition and the guarantee of civil liberties. This is why the former Senator of the first republic, Suemo Chia decried on Radio Benue current affairs discussion programmes; "On Issues of the moment on the topic: Ten 
years of Democracy in Nigeria" that "there is no democracy in the Nigeria's Fourth Republic. Rather, Nigeria has experienced ten years of non military intervention. He averred that the Nigerian state is still repressive, corrupt and anti-democratic. To him, these are happening because the Nigerian leadership is sick". From the 2011 to 2014, the situation is not different from what has been said above. Indeed the situation has gone worse with the high level of impunity being displayed all over the country in recent times. In particular the impunity displayed by the Peoples' Democratic Party (PDP) and the Presidency over the Rivers State Crisis where five PDP legislators in the Rivers State House of Assembly sought to impeach the Speaker of the House of 32 members with their connivance, using the Commissioner of Police in the State Mbu Mathew Mbu. This crisis has led to the closure of the House of Assembly for many months and the heightening of insecurity in the state. What is more corruption and stunted development is now pervading the whole of Nigeria. The rich are becoming richer while the poor are getting poorer every. Security of lives and properties particularly in the North-East Region of Nigeria and the Federal Government has been unable to successfully contain the situation. All these are a negation of true democracy.

\section{Conclusion and Recommendations}

We are concerned in this paper with the nature of governance in Nigeria's Fourth Republic. That much said, the paper concludes that the optimism generated by the return of civilian rule does not give much room for cheering. Rather, the Fourth Republic leaders have not successfully managed their "legitimacy" leaving their acclaimed democracy in a limbo. In the end, we only experience an uninterrupted civil rule from 1999 to date. The way out of this cul de sac is the citizens. They can only do this when they are organized. An organization that will ensure that the tenets of democracy are adhered to is whereby advocated. Ever since, the problem of Nigeria has been the political leadership who have failed themselves, the nation and the rule of law. The followership has also been blindly organizing a support for this class. Thus, we either struggle to change the fraudulent political process or it consumes the country.

Again, democracy it must be reiterated has no meaning without freedom and there is no freedom without the press. Thus, for there to be democracy, there must first of all, be freedom which makes the difference between enslavement and liberation. The masses must also be freely allowed to decide who leads them. They should also be allowed to participate on issues that affect their lives and concern directly and above all, elections must be free and fair as well as being periodic. Anything short of this cannot (and should not) be referred to as democracy.

[1]. Adeyemi, L. (2006) "Democracy and the Free Market" in Saliu, A. et al. (eds) Democracy and Development in Nigeria: Economic and Environmental Issues. Lagos Concept Publishers.

[2]. Ake, C. (1996) Is Africa Democratizing? Lagos: Malthouse Press.

[3]. Babawale, T. (2003). The State, Ethnic militia and the challenges of Democratic Government in Post Military Nigeria" in Babawale T. (Ed) Urban Violence, ethnic militias and the challenges of Democratic Consolidation in Nigeria, Lagos Malthous Press.

[4]. Bill, J.A. and Hardgrave Jr. (1973). Comparative Politics: The Quest for Theory, Columbus, Ohio: Charles E. Merrill Publishing Company.

[5]. Dahl, R. (1976). Modern Political Analysis Englewood Cliff: Prentice Hall Inc.

[6]. Dahl, R. (1989). Democracy and its Critics. New Haven: Yale University Press.

[7]. Elaigwu, J.I. (2004). "Democratic Government and Political Stability in Nigeria", Paper presented at the convocation lecture of Benue State University, Makurdi, $7^{\text {th }}$ May, 2004.

[8]. Enemuo, F.C. (1999). "Decentralization and Local Government: Models, Principles and Purposes", in Anifowose and Enemuo (ed). Elements of Politics, Lagos Malthouse press.

[9]. Igbokwe, J. (2009). Ten Years of Democracy in Nigeria. http//:www.hotmail.sundayjune2009.founders.org.

[10]. Nyityo, G. (2009). Economic Crisis and Credible Electoral Process: Mobilizing for Positive Change. Makurdi: Maxon Press.

[11]. Odo, A. (1983). How Local Governments Operate in Other Countries (America, Britain, France, Japan and the Soviet Union) with supplement on Nigeria, Department of Local Government Studies, Ahmadu Bello University, Zaria

[12]. Olaniyi, J. (2001). Introduction to Contemporary Political Analysis. Lagos: Fapsony Nigeria Ltd.

[13]. Oludoyi, S. (2006). "Economic Development Financing: Does the Existence of Democracy Really Matter? In Saliu, A et al. (eds) and Development in Nigeria: Economic and Environmental Issues. Lagos: Concept Publishers.

[14]. Oneche, E. et al. (2009) 1999-2009: Knocks, Kudos Trial Ten years of Democracy. http//:www.vanguard.org.

[15]. Parato, W. (1963). "The Mind of Society", (A Treatise on General Sociology). Translated by Andrew Bongrorno and Author Livingston, New York: Harcourt, Brace \& Co.

[16]. Shumpter, J. (1942). Capitalism, Socialism and Democracy. London Routledge.

[17]. Soueze, S. (2002).Deregulation of Down-Stream Sector of the Nigerian Economy. Htp//www.vanguard.com/articles.

\section{Newspapers}

Daily Trust April 1, 2009

Daily Trust October 28, 2008

Leadership June 21, 2009

This Day August 23, 2009

The Nation November 30, 2011

Vanguard, May 24, 2009 